\title{
PENDAPAT ZAHIRIYYAH \\ TENTANG BATASAN MELIHAT PEREMPUAN DALAM KHITBAH
}

\author{
Anis Nizar \\ Fakultas Agama Islam, Universitas Muhammadiyah Palangkaraya \\ anisnizar36I@gmail.com
}

\begin{abstract}
Abstrak
khitbah atau pinangan dalam Islam adalah diperbolehkan bahkan dianjurkan, tujuannya yaitu agar calon pasangan tersebut saling mengenal satu sama lain. Dalam proses khitbah, ada beberapa hal yang diperbolehkan, diantaranya yaitu kebolehan melihat perempuan yang dikhitbah. Akan tetapi, dalam proses ini tentu harus didampingi oleh mahram dari pihak perempuan dan tidak boleh dilakukan hanya berdua saja atau berkhalwat. Para ulama fikih juga sepakat akan kebolehan melihat perempuan yang dikhitbah, akan tetapi yang menjadi perdebatan adalah batasan dari melihat itu sendiri. Mayoritas ulama memperbolehkan melihat wajah dan telapak tangan untuk melihat kecantikan fisik dan kesuburannya. Sementara itu, pendapat yang paling ekstrem datang dari golongan Z $\{a>$ hiriyyah, di mana mereka memperbolehkan melihat seluruh anggota tubuh perempuan yang dikhit\{bah, baik yang tersembunyi maupun yang terlihat, dalam keadaan lalai maupun tidak lalai. Pendapat tersebut bersumber dari metode istinba $>t\{$ hukum yang digunakan, di mana mereka secara langsung melihat dhahir hadis tentang kebolehan melihat perempuan yang dikhit\{bah, dan di dalam hadis tersebut tidak ada batasan yang disebutkan secara rinci oleh Rasulullah SAW mengenai bagian yang boleh dan tidak boleh dilihat, serta hadis itu cenderung memiliki makna yang kuat bahwa seorang lak-laki boleh melihat seluruh anggota tubuh perempuan yang dikhit\{bah jika dia ingin serius menikahi perempuan tersebut.
\end{abstract}

Kata Kunci: Z\{a>hiriyyah, Batasan, Melihat Perempuan dalam Khit\{bah

\begin{abstract}
Khitbah or proposal to marriage In Islam is allowed and even encouraged, the purpose if for the prospective bride and groom to know each other. In the process of khitbah, there are several things that are allowed, including the ability to seeing woman in khitbah. However, this process must be accompanied by a female mahram and cannot be done in pairs. The fiqh schoolars agree for seeing women in khitbah, but they still debatable about limitation of seeing women in khitbah. The majority of religious scholars agrees that seeing face and palms to see woman's physical beauty and fertility is allowed. Moreover, the most extreme opinion comes from $Z\{a>$ hiriyyah which argues that seeing all parts of the female's body, whether hidden or visible, in khit\{bah in both unconscious and conscious condition is allowed. The opinion came from legal istinba>t method used, in which they directly saw dhahir hadith about the permissibility of seeing women in khit\}bah, while in fact, it was found that there was no limitaton mentioned in detail by the Prophet Muhammad in that hadith about which parts that can or cannot be seen. Moreover, the hadith likely tended to have a strong meaning that man could see all parts of female's body in khit\}bah if he seriously wanted to marry the woman.
\end{abstract}

Key words: Z\{a>hiriyyah, Limitation, Seeing Women in Khit $\{b a h$,

\section{Pendahuluan}

Lamaran atau khitbah merupakan langkah awal dari suatu pernikahan. Hal ini disyariatkan oleh Allah SWT sebelum dilaksanakannya akad nikah antara seorang laki-laki dan perempuan. Salah satu tujuannya adalah, agar masing-masing pihak mengetahui dan mengenal pasangan yang akan menjadi pendamping hidupnya nanti.. Sebagaimana firman Allah dalam surat al-Baqarah ayat 235 (Uwaidah, 2008: 4l9):

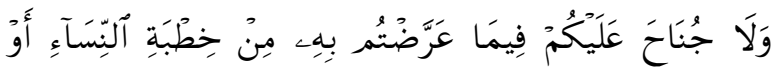

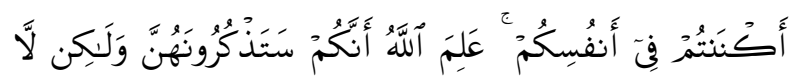

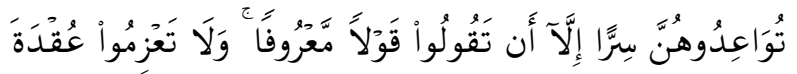

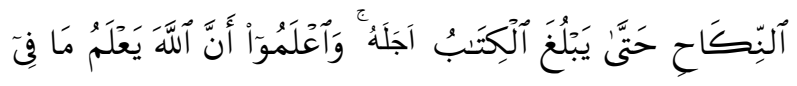

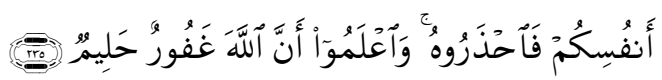

Artinya: Dan tidak ada dosa bagi kamu meminang wanita-wanita itu dengan sindiran atau kamu menyembunyikan (keinginan mengawini mereka) dalam hatimu. Allah mengetahui bahwa kamu akan menyebutnyebut mereka, dalam pada itu janganlah kamu mengadakan janji kawin dengan mereka secara rahasia, kecuali sekedar mengucapkan (kepada mereka) perkataan yang ma'ruf. dan janganlah kamu ber'azam (bertetap hati) untuk beraqad nikah, sebelum habis 'iddahnya. dan Ketahuilah bahwasanya Allah mengetahui apa yang ada dalam hatimu; Maka takutlah kepada-Nya, dan Ketahuilah bahwa Allah Maha Pengampun lagi Maha Penyantun. (Q.S. Al-Baqarah: 235)

Di samping untuk mengetahui dan mengenal pasangan yang akan menjadi pendamping hidupnya nanti, khitbah juga merupakan sebuah upaya agar perkawinan yang dilaksankannya nanti dapat membentuk keluarga yang sakinah mawaddah wa rahmah. Keluarga sakinah adalah dambaan bagi setiap orang yang membangun rumah tangga. Selain itu, tujuan perkawinan di dalam ajaran Islam adalah membangun keluarga yang damai, bahagia, tentram, dan sejahtera. Allah SWT menganjurkan agar kehidupan keluarga menjadi bahan pemikiran setiap insan dan hendaknya darinya dapat ditarik 
pelajaran berharga. Sebagaimana telah disebutkan dalam al-Qur'an surat ar-Rum ayat 2 I dan an-Nahl ayat 72 (Dlaifurrahman, 20I7, 4I).

Khit\{bah sendiri dapat dilakukan oleh laki-laki yang melamar itu sendiri atau pihak keluarga. Apabila keduanya setuju, maka khit\{bah terlaksana dan bagi perempuan tersebut dikenakan konsekuensi syara' (Zuhaily, 20l2). Hubungan antara laki-laki dengan perempuan selama masa antara peminangan dan perkawinan itu adalah sebagai hubungan laki-laki dan perempuan asing. Oleh karena itu, belum berlaku hak dan kewajiban di antara keduanya (Syarifuddin, 2003, 86).

Sementara itu, bagi calon suami, dengan melakukan khitbah akan mengenal empat kriteria calon isterinya, seperti yang diisyaratkan oleh Rasulullah SAW dalam sebuah hadisnya yaitu, wanita dinikahi karena empat hal, karena hartanya, keturunannya, kecantiknnya, dan karena agamanya, maka pilihlah wanita karena agamanya, maka akan memelihara tanganmu.

Persoalan khit\{bah ini memang disebutkan dalam al-Qur'an dan juga hadits Nabi SAW. Namun tidak ditemukan secara jelas dan terarah adanya perintah atau larangan melakukan peminangan sebagaimana perintah untuk mengadakan perkawinan dengan kalimat yang jelas, baik dalam al-Qur'an maupun dalam hadits Nabi SAW. Oleh karena itu, dalam menetapkan hukumnya tidak terdapat pendapat ulama' yang mewajibkannya. Adapun dalil-dalil tentang khit\{bah adalah sebagai berikut:

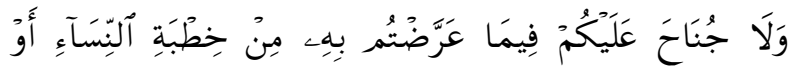

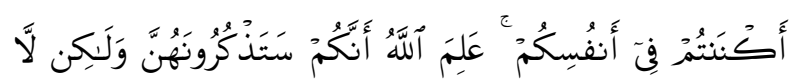

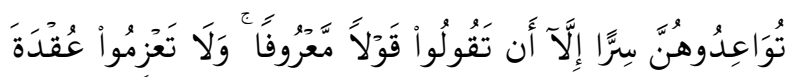

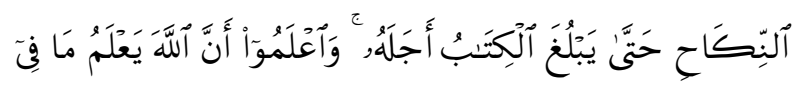

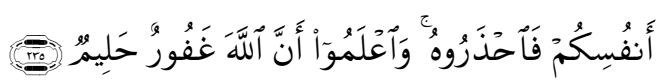

"Dan tidak ada dosa bagi kamu meminang wanitawanita itu dengan sindiran atau kamu menyembunyikan (keinginan mengawini mereka) dalam hatimu. Allah mengetahui bahwa kamu akan menyebut-nyebut mereka, dalam pada itu janganlah kamu mengadakan janji kawin dengan mereka secara rahasia, kecuali sekedar mengucapkan (kepada mereka) perkataan yang ma'ruf. dan janganlah kamu ber'azam (bertetap hati) untuk beraqad nikah, sebelum habis 'iddahnya. dan Ketahuilah bahwasanya Allah mengetahui apa yang ada dalam hatimu; Maka takutlah kepada-Nya, dan
Ketahuilah bahwa Allah Maha Pengampun lagi Maha Penyantun. (QS. al-Baqarah: 235)

$$
\begin{aligned}
& \text { عن المغيرة بن شعبة أنه خطب امرأة فقال له رسول الله أنظرت إليها ؟ } \\
& \text { قال لا قال: انظر إليها فإنه أحرى أن ئن يؤدم بينكما " رواه النسائي }
\end{aligned}
$$

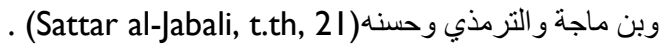
Artinya: "dari Mughirah bin Syu'bah, sesungguhnya dia telah mengkhitbah seorang perempuan, kemudian Rasulullah SAW berkata kepadanya: apakah kamu sudah melihatnya, Mughirah menjawab: tidak. Rasulullah SAW bersabda: lihatlah dia, karena yang demikian itu akan lebih melanggengkan perkawinan keduanya",

لا يبع الرجل على بيع أخبه و لا يخطب بعضكم على خطبة بعض (وفي

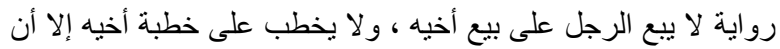

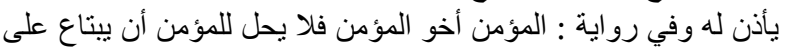

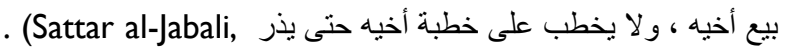

t.th, 20)

Artinya: "sebagian kalian tidak boleh membeli atau menawar atas sesuatu yang sudah dibeli atau ditawar oleh sebagian yang lain, dan sebagian kalian tidak boleh mengkhitbah atas khit\{bah sebagian yang lain." (dalam riwayat lain disebutkan:tidak boleh membeli atau menawar atas sesuatu yang sudah dibeli atau ditawar oleh saudaranya, dan tidak boleh mengkhit\{bah atas khit\{bah saudaranya yang lain, kecuali dengan izinnya. Dan dalam riwayat yang lain disebutkan: seorang mukmin itu adalah saudara bagi mukmin yang lain, maka tidak halal bagi seorang mukmin membeli atau menawar atas apa yang dibeli atau ditawar oleh saudaranya, dan tidak mengkhit\{bah atas khit\{bah saudaranya sampai dia meninggalkannya.

Dalam khitbah, laki-laki yang mengkhitbah ini dapat melihat perempuan yang dikhitbahnya. Melihat di sini hukumnya adalah sunnah, karena dengan melihatnya, akan diketahui identitas maupun pribadi perempuan yang akan dinikahinya tersebut (Rofiq, 2017, 82). Rasulullah SAW bersabda:

$$
\text { فليفعل خطب احدكم المر أة فإن اسنطاع أن ينظر منها مايدعو الى نكاحها }
$$

Artinya: "bila seseorang di antara kamu meminang perempuan dan dia mampu melihatnya yang akan mendorong untuk menikahinya, maka lakukanlah" (Ghazaly, 2006, 85).

Untuk meminang seorang perempuan, terdapat beberapa syarat yang harus dipenuhi, yaitu:

a. Tidak ada penghalang yang dapat menghalangi pernikahan dengan perempuan yang sedang dikhit\{bah. Penghalang tersebut ada yang bersifat abadi dan ada yang bersifat sementara (Jad, 2008, 405). 
b. Tidak sedang dalam pinangan orang lain, sebagaimana yang diriwayatkan dari Ibnu Umar bahwa Rasulullah SAW bersabda:

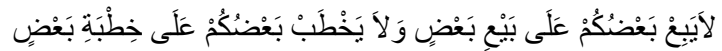

Artinya: sebagian kalian tidak boleh membeli atau menawar atas sesuatu yang sudah dibeli atau ditawar oleh sebagian yang lain, dan sebagian kalian tidak boleh mengkhit\{bah atas khit\{bah sebagian yang lain.

Larangan meminang perempuan yang sudah dipinang oleh orang lain adalah bertujuan untuk menghindari adanya kebencian bahkan pemutusan tali silaturrahim. Dengan demikian, pernikahan yang nantinya akan dilaksanakan juga terhindar dari kebencian, rasa permusuhan dan juga akibat-akibat buruk lainnya.

Selanjutnya, juga terdapat beberapa hal yang diperbolehkan bagi peminang terhadap perempuan yang sedang dipinangnya (dikhit\{bah), diantaranya yaitu (Jad, 2008, 408):

a. Melihat perempuan yang dipinang (dikhit\{bah)

b. Berbicara dengan perempuan yang dikhit\{bah disertai mah\{ram atau salah satu dari keluarga perempuan, seperti saudara laki-laki, saudara perempuan, atau ibunya.

c. Tidak diperbolehkan bagi laki-laki yang mengkhit\{bah untuk berduaan dengan perempuan yang dikhit\{bah tanpa adanya orang lain.

Dalam Islam sendiri, melihat perempuan yang dikhit\{bah memang diperbolehkan. Namun, batas-batas dalam melihat itu menimbulkan perselisihan di kalangan ulama. Imam Ma>lik dan mayoritas ulama menyatakan bahwa diperbolehkan melihat wajah dan telapak tangannya saja (Ghazaly, 2006, 75), wajah untuk menggambarkan kecantikan fisiknya sedangkan telapak tangan untuk melihat kesuburannya. Sebagai tambahan, ulama $\mathrm{H}$ \{anafi memperbolehkan untuk melihat kedua kakinya. Sementara itu, pendapat masyhur di kalangan madhhab Imam Ahmad, diperbolehkan melihat bagian luar tubuh secara umum, seperti wajah, leher, dua telapak tangan, dan kedua kaki (as-Subki, 2010, 82). Ulama lain seperti al-Auza>'i berpendapat bahwa, boleh melihat bagian-bagian yang berdaging. Sedangkan Dawud az $\{-Z\{a>$ hiri berpendapat bahwa, boleh melihat seluruh badan, karena hadits Nabi SAW yang membolehkan melihat waktu meminang tidak menyebutkan batas-batasnya (Syarifuddin, 2003, 86).

Dawud az-Zahiri ini merupakan salah satu tokoh dan juga pencetus madhhab Zahiriyyah. Madhhab Z\{a>hiriyyah adalah madhhab yang menjadikan nash sebagai satu-satunya sumber dalam penetapan hukum Islam. Artinya, tidak ada celah bagi pendapat-pendapat dalam menetapkan hukum Islam. Oleh karena itu, madhhab ini menafikan segala hal yang diyakini oleh kelompok ahlu ra'yi. Mereka juga tidak mengaplikasikan qiya>s, istih\{sa>n, mas\{lah\{ah mursalah, sad adh-dhara>i'. Apabila nash tidak ada, mereka akan mengambil hukum dengan istish $\{a>b$ (pada dasarnya, segala sesuatu itu hukumnya adalah boleh) (Zahrah, t.th, 506).

Terdapat dua tokoh besar dalam madhhab ini, pertama, Daud al-Ashfahani yang merupakan pencetus madhhab Z\{a>hiriyyah, karena dia adalah orang yang pertama kali memperkenalkan madhhab Z\{a>hiriyyah. Yang kedua, adalah Ibnu $\mathrm{H}\{a z m$ al-Andalusy, meskipun dia tidak memiliki sumbangsih dalam mendirikan madhhab ini, namun dia memaparkan dalil-dalil dalam madhhab Z\{a>hiriyyah serta menjelaskannya dengan sangat jelas. Dia juga sangat berpegang teguh kepada madhhab Z\{a>hiriyyah melebihi Daud az $\{-Z\{a>$ hiri itu sendiri (Zahrah, t.th, 507).

\section{Metode Penelitian}

Penelitian ini merupakan normatif atau disebut juga dengan penelitian pustaka (kajian literatur) (Soekanto, 2006), yaitu penelitian yang sumber data primernya berasal dari buku. Oleh karena itu, pengumpulan bahan hukumya dilakukan dengan cara dokumentasi, dengan cara: menentukan data (tulisan) yang akan dikumpulkan terkait dengan 'iddah, mengidentifikasi judul-judul buku atau kitab yang relevan dan berkaitan dengan 'iddah, membaca dan mempelajari buku-buku yang ada kaitannya dengan permasalahan dalam penelitian ini, membuat kesimpulan dari apa yang telah dibaca. Pendekatan yang digunakan adalah pendekatan konseptual, sedangkan teknik analisisnya adalah dengan cara mengedit, mengklasifikasi, menganalisis dan menyimpulkan. Sementara itu, pengecekan keabsahan data akan dilakukan dengan dengan pola triangulasi pada bahan data, teori dan peneliti.

\section{Pembahasan}

\section{Batasan Melihat Perempuan dalam Khitbah}

Pada saat berlangsungnya khit\{bah, laki-laki yang mengkhit\{bah diperbolehkan melihat perempuan yang dikhit\{bah. Kebolehan melihat ini didasarkan kepada hadist Nabi SAW dari Jabir menurut riwayat Ahmad dan Abu Daud, yang berbunyi:

$$
\text { إذا خطب احدكم المر أة فإن استطاع أن ينظر منها مايدعو الى نكاحها }
$$

Artinya: "bila seseorang di antara kamu meminang perempuan dan dia mampu melihatnya yang akan 
mendorong untuk menikahinya, maka lakukanlah" (Ghazaly, 2006, 85).

حديث المغيرة بن شعبة رضي الله عنه أنه خطب امر أة فقال النبي صلى إلى إنه

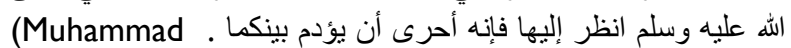
bin Isa, 1975, 389),

Hadis Mughirah bin Syu'bah RA, bahwa dia melamar seorang perempuan, maka Rasulullah SAW bersabda: lihatlah kepadanya, karena itu akan melanggengkan kalian berdua. (HR. Imam 5, kecuali Abu Dawud.)

Dalam hadis-hadis tersebut, Rasulullah tidak memberikan batasan tertentu kepada Mughirah, tentang kadar yang boleh dilihat oleh si peminang, bahkan perintah Rasulullah itu masih mutlak, dalam batas-batas yang patut menurut adat lingkungan setempat. Sebagaimana yang diketahui, bahwa Islam tidak memperbolehkan bagi laki-laki untuk melihat perempuan kecuali muka dan telapak tangan, selain kedua bagian itu tidak diperbolehkan. Sebab hal itu bertentangan dengan nilai-nilai moral dan akhlak serta aturan-aturan hidup, yang dapat menimbulkan kerusakan di bumi ini. Oleh karena itu, Islam memperbolehkan melihatnya hanya dalam rangka peminangan (al-Khauly, 1988, 67).

Tidak adanya batasan tertentu yang disebutkan oleh Rasulullah dalam hadis tentang peminangan (khit\{bah), menimbulkan perdebatan di kalangan ulama tentang batasan kebolehan melihat perempuan yang dipinang (khit\{bah) tersebut. Dalam hal ini para ulama terbagi menjadi beberapa pendapat, yaitu:

1. Diperbolehkan melihat wajah dan telapak tangan (mayoritas ulama)

2. Diperbolehkan melihat wajah, telapak tangan, kedua kaki (ulama $\mathrm{H}\{\mathrm{a}>$ nafi)

3. Diperbolehkan melihat bagian luar tubuh secara umum, seperti wajah, leher, dua telapak tangan, dan kedua kaki. (Imam Ah\{mad) (as-Subki, 2010, 82).

4. Diperbolehkan melihat bagian-bagian yang berdaging (al-Auza>'i)

5. Diperbolehkan melihat semua anggota badan (Dawud az\{-Z\{a<hiri) (Syarifuddin, 2003, 86).

Adapun pembahasan dalam penelitian ini lebih difokuskan pada pendapat terakhir yang memperbolehkan melihat semua anggota tubuh perempuan yang sedang dikhit\{bah. Sebagaimana perkataan Abu Dawud az\{-Z\{a>hiri sendiri:

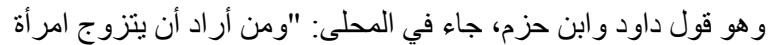

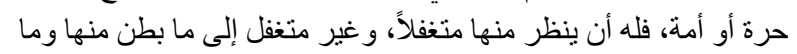

$$
\begin{aligned}
& \text { ظهر (Hazm al-Andalusi, t.th. I6I) }
\end{aligned}
$$

Dan ini adalah perkatan Dawud dan Ibnu $\mathrm{H}\{a z m$, tertulis dalam kitab al-Muh\{alla>: "Barang siapa yang ingin menikahi perempuan, baik merdeka ataupun budak, boleh baginya untuk melihat perempuan tersebut dalam keadaan lalai maupun tidak lalai, sampai pada batasan yang tersembunyi maupun yang terlihat." قال الثوكاني في نيل الأوطار: "فذهب الأكثر إلى أنه يجوز إلى الوجه

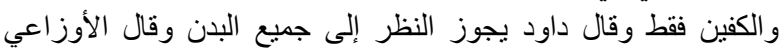

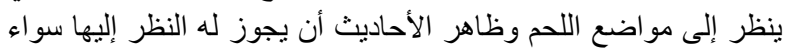

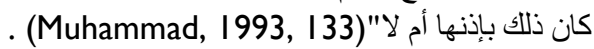
Syaukani berkata dalam Nail al-Aut\{a>r: "mayoritas ulama berpendapat, hanya boleh melihat wajah dan telapak tangan saja, dan Dawud berkata: boleh melihat seluruh anggota badannya, dan Auza>'i berkata: boleh melihat pada bagian-bagian daging, dan yang tercantum di dalam hadis-hadis bahwa boleh melihat walaupun itu dengan izinnya ataupun tidak".

\section{Hasil Analisis}

\section{Pendapat Z \{a>hiriyyah Tentang Batasan Melihat Perempuan dalam Khitbah}

Dari beberapa pendapat para ulama tentang batasan melihat perempuan dalam khit\{bah, pendapat yang paling ekstrem adalah pendapat dari Dawud az\{Z $\{a<$ hiri, di mana laki-laki yang meminang diperbolehkan melihat seluruh anggota tubuh perempuan yang dipinangnya. Padahal, sebagaimana yang diketahui, bahwa Islam tidak memperbolehkan bagi laki-laki untuk melihat perempuan kecuali wajah dan telapak tangan, selain kedua bagian itu tidak diperbolehkan. Sebab hal itu bertentangan dengan nilainilai moral dan akhlak serta aturan-aturan hidup, yang dapat menimbulkan kerusakan di bumi ini. Oleh karena itu, Islam hanya memperbolehkan melihat perempuan dalam rangka peminangan (al-Khauly, 1988, 67).

Pendapat Dawud az $\{-Z\{a<$ hiri ini dapat dijumpai dalam penjelasan berikut:

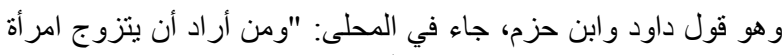

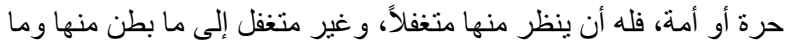

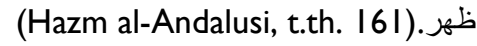

Dan ini adalah perkatan Dawud dan Ibnu $\mathrm{H}\{$ azm, tertulis dalam kitab al-Muh\{alla> : "Barang siapa yang ingin menikahi perempuan, baik merdeka ataupun budak, boleh baginya untuk melihat perempuan tersebut dalam keadaan lalai maupun tidak lalai, sampai pada batasan yang tersembunyi maupun yang terlihat."

$$
\begin{aligned}
& \text { قال الثوكاني في نيل الأوطار: "فذهب الأكثر إلى أنه يجوز إلى الوجه }
\end{aligned}
$$

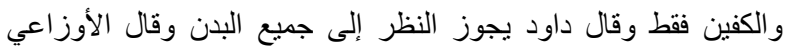

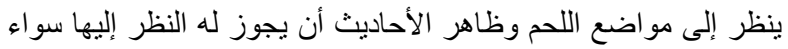

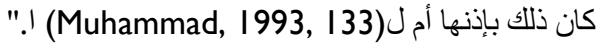


Syaukani berkata dalam Nail al-Aut\{a>r: "mayoritas ulama berpendapat, hanya boleh melihat wajah dan telapak tangan saja, dan Dawud berkata: boleh melihat seluruh anggota badannya, dan Auza'i berkata: boleh melihat pada bagian-bagian daging, dan yang tercantum di dalam hadis-hadis bahwa boleh melihat walaupun itu dengan izinnya ataupun tidak".

Dari penjelasan tersebut dapat dilihat bahwa menurut golongan $Z\{a>$ hiriyyah, laki-laki yang ingin menikahi perempuan diperbolehkan melihat perempuan tersebut sampai pada batasan yang terlihat maupun tidak terlihat. Sedangkan dalam perkataan selanjutnya dijelaskan bahwa diperbolehkan melihat seluruh anggota badan perempuan yang ingin dinikahinya. Argumen mereka adalah:

I. Hadis dari Wahibah

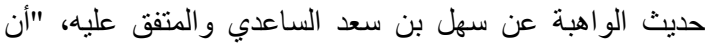

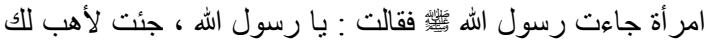

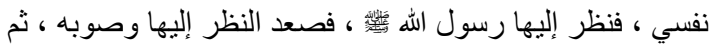

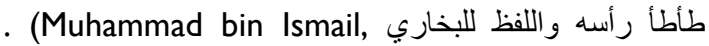

Hadis al-Wahibah, dari Sahal bin Sa'ad as-Sa'idi, dan muttafaq 'alaih: "bahwa seorang perempuan mendatangi Rasulullah SAW, dan dia berkata: aku datang kepadamu ya Rasul untuk memberikan diriku, maka Rasulullah memandangnya, melihatnya dari atas ke bawah kemudian kepalanya mengangguk-angguk. Dan lafadz milik Bukhari”.

2. Hadis dari Mughirah bin Syu'bah حديث المغيرة بن شعبة رضي الله عنه أنه خطب امر أة فقال النبي

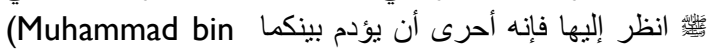
Isa,

1975, 389).

Hadis Mughirah bin Syu'bah RA, bahwa dia melamar seorang perempuan, maka Rasilullah SAW bersabda: lihatlah kepadanya, karena itu akan melanggengkan kalian berdua. (HR. Imam 5, kecuali Abu Dawud.

3. Hadis dari Abu Hurairah

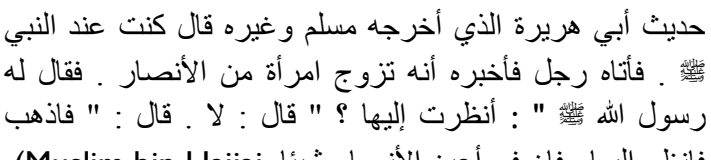

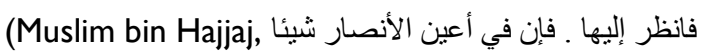

Bahwa aku berada di sisi Rasululah SAW, maka dia kedatangan seorang pemuda yang mengabarkannya bahwa dia telah menikahi seorang perempuan dari kalangan Anshar, kemudian Rasulullah Saw bertanya kepadanya: "apakah kamu melihatnya sebelumnya?, dia menjawab : "tidak", maka Rasulullah SAW bersabda: pergilah dan lihatlah dia. Maka sesungguhnya dalam mata perempuan tersebut terdapat sesuatu (kecacatan)"

4. Hadis dari Jabir

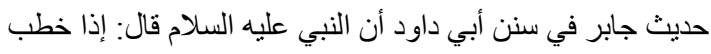
أحدكم المرأة فإن استطاع أن ينظر إلى إلى ما يدعوه إلى نكالي نكاحها

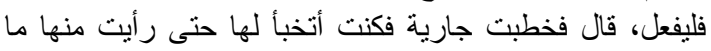

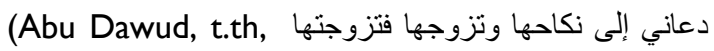

228).

Hadis Jabir dalam Sunan Abi Dawud, sesungguhnya Nabi SAW bersabda: apabila salah satu dari kalian melamar seorang perempuan, jika dia mampu untuk melihat sesuatu yang bisa membuatnya tertarik untuk menikahinya maka lakukanlah, Jabir berkata: maka aku melamar seorang budak, kemudian aku mngintipnya sampai aku bisa melihat sesuatu yang membuatku tertarik untuk menikahi dan mengawininya, maka aku menikahinya.

5. Hadis dari Muhammad bin Maslamah

حديث محمد بن مسلمة عند ابن ماجة وعند البيهقي في السنن

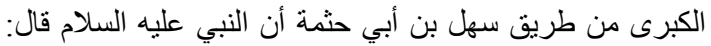

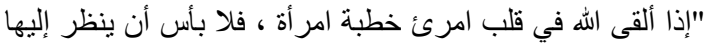

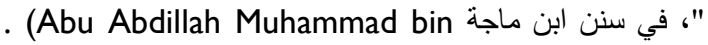
Yazid, t.th, 599)

Hadis Muhammad bin Maslamah dalam Sunan Ibnu Majah dan Baihaqi di Sunan Kubranya, dari Sahl bin Abi Hatsmah, bahwa Rasulullah SAW bersabda: "apabila Allah SAW menjadikan di hati seseorang untuk melamar perempuan, maka tidak apa-apa baginya untuk melihat perempuan tersebut."

6. Hadis dari Imam as-San'ani

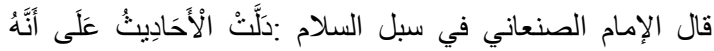

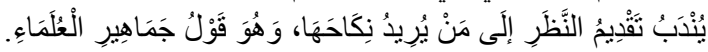

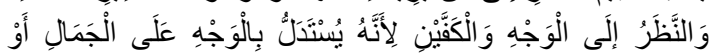

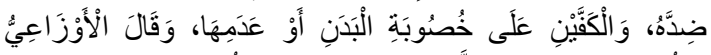

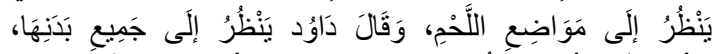

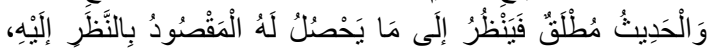

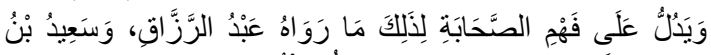

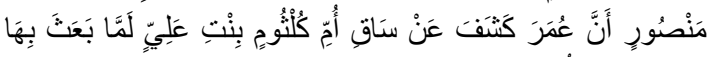

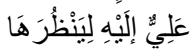

Imam San'ani berkata di dalam Subul as-Sala $>m$ bahwa, (hadis hadis tentang khit (bah) menunjukan tentang sunahnya melakukan nazar sebelum menikahi perempuan, dan ini merupakan 
pendapat mayoritas ulama. Nazar tersebut dilakukan dengan melihat wajaha dan telapak tanga,n karena dengan melihat wajahnya dapat diketahui cantik atau tidaknya perempuan tersebut. Sedangkan dari telapak tangan dapat mengetahui kemampuan perempuan dalam memberi keturunan. Auza'i berkata boleh melihat pada tempat tempat berdaging, Abu Dawud berkata boleh melihat pada seluruh tubuh, karena hadis hadis tentang nazar ini sifatnya mutlaq maka di perbolehkan melihat apa apa yg dengannya tercapai tujuan tersebut. dan yang menunjukan aplikasi dari pemahaman sahabat sebagaimna yang di riwayatkan dari Abdur Razaq dan Said bin Mansur bahwa, Umar menyingkap Umu Kulsum binti Ali hingga terlihat betisnya ketika Ali meyuruh Umar untuk mengkhit\{bahnya (Imam as-San'ani, 1979, 980).

Hadist-hadist tersebut adalah hadist yang dijadikan acuan oleh para ulama golongan Z\{a $>$ hiriyyah dalam menentukan batasan melihat perempuan yang dikhit\{bah. Dan dari hadist-hadist tersebut dapat disimpulkan, bahwa seorang laki-laki yang ingin menikahi perempuan, dianjurkan untuk melihatnya terlebih dahulu, serta tidak disebutkan bagian mana saja yang boleh dan tidak boleh dilihat dalam proses khit\{bah. Oleh karena itu, golongan Z $\{a>$ hiriyyah menyatakan bahwa diperbolehkan bagi laki-laki untuk melihat seluruh anggota tubuh perempuan yang dikhit\{bahnya, karena tidak ada batasan yang disebutkan dalam hadis-hadis tentang khit\{bah di atas. Hal itu sesuai dengan metode yang digunakan oleh golongan ini, yaitu menggunakan metode $Z$ \{a>hiriyyah.

Sebagaimana dijelaskan dalam bab terdahulu, golongan $Z\{a>$ hiriyyah ini mempunyai metode istinba>t\{ hukum yang tidak sama dengan madhhabmadhhab lainnya. Diantaranya yaitu, mereka tidak menggunakan qiya>s, istih\{sa>n dan mas\{lah\{ah. Sedangkan, apabila dilihat dari namanya "Z\{a>hiriyyah", hal itu sudah dapat menunjukkan tentang metodologi yang mereka gunakan, yaitu hanya mengambil istinba>t\{ hukum dari dalil-dalil al-Qur'an dan hadis-hadis shahih berdasarkan dhahir ayat serta hadis tersebut tanpa menggunakan hal-hal seperti ra'yu dan lain sebagainya.

Bagi golongan dalam madhhab ini, tidak ada alasan untuk mengambil selain dari apa adanya suatu nash, dan oleh karena itu tidak ada keperluan terhadap ta'wi>I dan semacamnya. Jadi, metode Z\{a>hiri itu dalam operasionalnya menghindari ta'wi>l dan sematamata melakukan penalaran hukum berdasarkan arti yang nyata, terang, mudah ditangkap oleh akal. Dan makna yang diambil itu sesuai dengan tutur bahasa dan tujuan pengucapannya, serta pendengar pun dapat memahaminya sesuai dengan pemakaian komunitas penuturnya (Siregar, 2009, 63). Sehingga, pendapat yang dihasilkan dari istinba>t\{ hukumnya cenderung tampak ekstrem dan keras, serta sulit diterima oleh masyarakat umum pada zamannya.

Salah satu contohnya adalah pandangan mereka tentang hadis khit\{bah yang telah disebutkan sebelumnya. Pada hadis tersebut, para ulama Z $\{a>$ hiriyyah mengambil kesimpulan berdasarkan dhahir hadis, bahwa seorang laki-laki boleh melihat seluruh anggota tubuh perempuan yang akan dikhit\{bahnya karena tidak ada batasan yang disebutkan secara rinci oleh Rasulullah SAW mengenai bagianbagian yang dilarang atau bagian-bagian yang diperbolehkan untuk dilihat. Bahkan dalam hadis tersebut, seorang sahabat mengikuti atau mematamatai seorang perempuan sampai dia melihat apa yang menjadikannya tertarik untuk menikahi perempuan tersebut. Maka ketika dia sudah melihat bagian-bagian yang dia anggap menarik, dia akan segera menikahinya.

Interpretasi yang keliru terhadap teks atau nash agama yang terdapat dalam kitab suci al-Qur'an, hadishadis Rasulullah SAW, dan fikih itu sendiri seringkali difahami secara apa adanya sesuai dengan teks tertulis, (sebagaimana metode istinba>t\{ hukum yang digunakan oleh golongan $Z\{a>$ hiriyyah). Salah satu contoh yang perlu diinterpretasi ulang adalah figh muna>kah\{a>t, secara lebih spesifik adalah interpretasi terhadap pendapat $Z\{a>$ hiriyyah tentang batasan melihat perempuan dalam khit\{bah. Di mana dalam pendapat itu dikatakan bahwa laki-laki diperbolehkan melihat seluruh anggota tubuh perempuan yang dikhit\{bah, sedangkan seperti yang diketahui bersama, bahwa mayoritas ulama hanya memperbolehkan melihat wajah dan telapak tangan perempuan yang dikhit\{bah.

\section{Kesimpulan}

Dalam rangka khit\{bah, Z\{a>hiriyyah berpendapat bahwa laki-laki yang ingin menikahi perempuan diperbolehkan melihat seluruh anggota tubuh perempuan, baik yang terlihat maupun tidak terlihat, dalam keadaan lalai maupun tidak lalai. Artinya, laki-laki itu diperbolehkan melihat seluruh anggota tubuh perempuan yang dikhit\{bahnya untuk membuatnya tertarik dan kemudian menikahi perempuan itu. Pendapat yang demikian ekstrem itu bersumber dari metodologi istinba>t\{ hukum yang mereka gunakan, di mana mereka hanya memahami hukum dari dalil-dalil al-Qur'an dan hadis-hadis shahih berdasarkan dhahir ayat dan hadis tersebut tanpa menggunakan hal-hal seperti ra'yu dan lain sebagainya. Bagi golongan dalam madhhab ini, tidak ada alasan untuk mengambil selain 
dari apa adanya suatu nash, dan oleh karena itu tidak ada keperluan terhadap ta'wi>l dan semacamnya. Jadi, metode $Z\{a>$ hiri itu dalam operasionalnya menghindari ta'wi>l dan semata-mata melakukan penalaran hukum berdasarkan arti yang nyata, terang, mudah ditangkap oleh akal. Dan makna yang diambil itu sesuai dengan tutur bahasa dan tujuan pengucapannya, serta pendengar pun dapat memahaminya sesuai dengan pemakaian komunitas penuturnya. Sehingga, pendapat yang dihasilkan dari istinba>t\{ hukumnya cenderung tampak ekstrem dan keras, serta sulit diterima oleh masyarakat umum pada zamannya. Sebagaimana pendapat tentang batasan melihat perempuan yang dikhit\{bah ini. Karena mereka mengambil kesimpulan berdasarkan dhahir hadis tentang khit\{bah yang mana Rasulullah SAW tidak menyebutkan secara rinci mengenai batasan-batasan bagian tubuh yang boleh dan tidak boleh dilihat dalam hadis tersebut. Dengan demikian, mereka menyimpulkan bahwa laki-laki diperbolehkan melihat seluruh anggota tubuh perempuan yang dikhit\{bah.

\section{Daftar Pustaka}

As-Subkhi, Ali Yusuf. 2010. Figh Keluarga: Pedoman Berkeluarga dalam Islam. Jakarta: AMZAH.

Daud, Abu bin Salman. t.th. Sunan Abu Dawud. jilid 2. Beirut: Maktabah 'Ashriyyah.

Ghazaly, Abd. Rahman. 2006. Figh Munakahat. Jakarta: Kencana.

Ibnu Hazm al-Andalusi. t.th. al-Muh\{alla $>$ bi al-A>tha>r. Juz 9. Beirut: Da>r al-Fikr.

Imam as-San'ani. 1979. Subul as-Salam Sharhu Bulugh alMaram. Juz 3. Kairo: Dar al-Hadis.

Al-Khauly, Bahay. 1988. Islam dan Persoalan Wanita Modern. Solo: Ramadhani.

Muhammad bin Ali. 1993. Nailul Aut\{a>r. Jilid 6. Kairo: $\mathrm{Da}>\mathrm{r}$ al-Hadits.

Muhammad bin Isa. 1975. Sunan at-Turmudzi. jilid 3. Shirkah Maktabah wa Mat $\{$ ba'ah Mus $\{\mathrm{t}\{\mathrm{ofa}>$ al$\mathrm{Ba}>$ bi al-H\{alabi.

Muhammad bin Ismail. 1422 H. S\{ahi>h Bukha>ri. jilid 7. $\mathrm{Da}>\mathrm{r}$ at $\{-\mathrm{T}\{$ uqu an-Naja $>\mathrm{h}$.

Muhammad, Abu Abdillah bin Yazid. t.th. Sunan Ibnu Ma>jah. jilid I. Ih\{ya>' al-Kutub al-'Arabiyyah.
Muslim bin Hajjaj. t.th. S\{ahi>h Muslim. jilid 2. Beirut: $\mathrm{Da}>r$ Ih\{ya>' at-Tura>th al-'Arabi.

Rofiq, Ahmad. 2017. Hukum Perdata Islam di Indonesia. Depok: Raja Rajawali Pers.

Sattar al-Jabali, Mohammad Abdus. t.th. al-Ah\{wa>l ashShakhs\{iyyah fi> ash-Shari>'ah al-Isla>miyah

Siregar, Amri. 2009. Ibn Hazm: Metode Zahiri dalam Pembentukan Sumber Hukum Islam. Yogyakarta: Belukar.

Soekanto, Soerjono. dan Sri Mamudji. 2006. Penelitian Hukum Normatif. Jakarta: Rajawali Press.

Syarifuddin, Amir. 2003. Garis-Garis Besar Figh. Jakarta: Kencana.

Uwaidah, Muhammad, Kamil. 2008. Fiqh Wanita. Terj: M. Abdul Ghoffar. Jakarta: al-Kautsar.

Zahrah, Muhammad Abu. t.th. Ta>ri>kh al-Madha>hib al-Isla>miyah. Kairo: Da>r Fikr al-'Araby.

Dlaifurrahman, Muhammad. "Upaya Membangun Keluarga Sakinah”. Jurnal Hadratul Madaniyah. Volume 4 Issue I, Juni 2017.

$\mathrm{MH}$, Ariyadi SHI. "Metodologi Istinbath Hukum Prof. Dr. Wahbah az Zuhaili Oleh." (2017).

Norcahyono, Norcahyono, and Ariyadi Ariyadi. "Pandangan Majlis Tarjih Muhammadiyah Kalimantan Tengah Tentang Tindakan Euthanasia Dalam Pendidikan Waris Islam." Tunas: Jurnal Pendidikan Guru Sekolah Dasar 5.I (2019): 50-6I.

Ariyadi, Ariyadi. "Tindak Pidana Pelaku Eksploitasi Seksual pada Anak Menurut Hukum Islam." Jurnal Hadratul Madaniyah 6.I (2019): 4367. 